\title{
Custo-benefício do sistema construtivo Steel Framing
}

Cássia Fernanda Borges Da Silva1; Diego Mendonça Tormim Soares²; Eduardo Lorenti Simoni;

Gustavo Eurípedes De Lima4; Jéssica Cristina Barboza ${ }^{5}$; João Paulo Costa Manita6;

Thiago Mendes Ferreira7; Carolina Oliveira Pinto ${ }^{8}$.

1, 2, 3, 4, 5, 6, 7, 8 UNIUBE - Universidade de Uberaba

jessica.crist.b@gmail.com e carolina.pinto@uniube.br

\section{1 - Introdução}

O Steel Framing se apresenta como um sistema construtivo inovador no ramo da construção civil brasileira, trazendo grandes vantagens sobre a obra de alvenaria convencional e sendo atualmente muito utilizado na construção de casas populares. Por usar materiais leves e utilizar menos material por volume construído, o Steel Framing é um sistema construtivo a seco bem estruturado, reduz a quantidade de resíduos produzidos em obra, pois seus materiais são recicláveis e reaproveitáveis.

A montagem é rápida com a obra limpa e seca, minimizando o uso dos recursos naturais $e$ geração de entulhos. A execução das casas requer mão de obra qualificada para que as etapas possam ser respeitadas e controladas, pois erros não são toleráveis. Seu custo pode ser um pouco mais elevado que da alvenaria convencional, entretanto são maiores os ganhos com o tempo, agilidade, produtividade e qualidade dos materiais empregados.

É um sistema estruturado em perfis de aço galvanizado formado a frio que originam seu esqueleto sob uma fundação comum nivelada e que se pode empregar vários tipos de revestimentos internos e externos como gesso acartonado de drywall, placas cimentícias, réguas de PVC, chapas de madeira Oriented Strand Board entre outras, além de ainda permitir o assentamento de revestimento cerâmico convencional sobre as placas.

Esse sistema surgiu no século XIX nos Estados Unidos quando a população do país crescia fazendo-se necessário recorrer aos materiais disponíveis localmente e a métodos práticos para a construção de moradias em pouco tempo. As primeiras casas foram construídas em madeira, sendo por isso o sistema inicialmente chamado de Wood Frame. Com a revolução industrial e depois com o término da Segunda Guerra Mundial, o aço era um recurso abundante, resistente e fácil de ser conformado. Assim após anos esse sistema foi aperfeiçoado e cada vez mais industrializado, chegando ao Brasil por volta de 1998 e ganhando cada vez mais espaço na construção.

Esse projeto tem como objetivo comparar o custo-benefício da construção de uma casa popular de alvenaria convencional com de uma casa construída no modelo Steel Framing para a construção de casas populares, através de revisões de literatura.

\section{2 - Materiais e métodos}

O trabalho foi desenvolvido por meio de levantamentos na literatura acadêmica relacionados à Steel Framing, publicados entre os anos de 2001 e 2014. Essas publicações foram buscadas em vários bancos de dados como scielo, periódicos capes e em repositórios, publicações, simpósios e congressos de universidades como UFSCAR, UFMG, UFRJ, UNB, UNICAMP, UFOP, USP entre outras, além de outros congressos importantes como Construmetal. Além disso foram procurados na Biblioteca Central da Uniube livros, revistas e manuais. Os livros e manuais mais relevantes são do CBCA - Centro Brasileiro de Construção em Aço.

Através da pesquisa e leitura bibliográfica do assunto será estudado o sistema construtivo a seco Steel Framing a fim de conhecer e entender cada uma de suas etapas, métodos e técnicas envolvidas, assim avaliando vantagens, custobenefício e seus ganhos na construção de casas populares de em média $40 \mathrm{~m}^{2}$, fazendo uma relação comparativa entre o sistema construtivo em estudo e o sistema construtivo convencional de alvenaria.

\section{3 - Resultados e discussão}

A construção civil convencional brasileira atual é executada com materiais agressivos em sua produção, que são poluentes durante a sua extração, e esses materiais depois de utilizados acabam gerando o entulho e causando o impacto ambiental. Steel Framing é um método construtivo industrializado, onde utiliza-se esqueleto estrutural fabricado com aço galvanizado formado a frio e fechamentos verticais de chapas delgadas, diferente de alvenaria convencional que usa tijolos, argamassa de cimento, reboco e emboço.

O materiais utilizados no Steel Framing garantem proteção termoacústica, diminuindo os gastos energéticos da edificação e prevenindo a propagação de grandes incêndios. Esse sistema construtivo aceita qualquer tipo de revestimento, é flexível, devido à facilidade de reformas e ampliação.

Por utilizar materiais leves, o peso próprio da construção é menor, economizando com fundação

www.uniube.br/entec - UNIUBE Campus Aeroporto - Uberaba/MG 
e possibilitando versatilidade de projeto. É um sistema que trabalha somente com a fixação estrutural de peças em aço reduzindo o tempo gasto em montagem e assentamento de material, e com componentes de alto controle de qualidade o que torna sua estrutura resistente a ações de desgaste causadas pelo clima, tempo e por agentes biológicos. Embora tanta qualidade implique maiores custos que a alvenaria convencional, o aumento da produtividade e diminuição do desperdício de materiais evita que ocorra impacto ambiental,, assim aumentando o custo-benefício e disponibilizando milhares de moradias com qualidade em menos tempo à população que está em contínuo crescimento.

A alvenaria convencional por ser mais pesada aparenta ser mais resistente e seus materiais mais duráveis. Entretanto o aço garante resistência e estabilidade necessária para a edificação, os materiais de revestimento são resistentes a esforços e pequenos eventuais impactos, além de apresentarem durabilidade, garantia em longo prazo e possibilidade de pequenos reparos.

No quesito ambiental, a construção convencional causa grande impacto ambiental para produção das matérias-primas, utilizadas nos materiais, e na geração excessiva de resíduos pouco reaproveitáveis ou recicláveis, enquanto que o Steel Framing produz menos resíduos e potencialmente recicláveis e reaproveitáveis, se mostrando como uma solução aos impactos por geração de resíduos da construção.

Esse sistema construtivo não é um sistema totalmente aceito e difundido no Brasil, pois ainda há muitas dúvidas e preconceitos sobre sua resistência, durabilidade em longo prazo e eficiência termoacústica. Entretanto, tem expandido em todo o território brasileiro com sua eficiências e grandes vantagens beneficiando não só construtores e empresas, mas a população com o sistema de casas populares, se mostrando como uma mudança inovadora no processo de construção civil para as firmas que procuram uma visão mais ecológica e econômica em suas construções, sendo que uma obra que desperdiça menos polui menos e economiza mais tanto em recursos como verbas e proporcionando moradia a muitas famílias.

\section{4 - Considerações finais}

O Steel Framing surge como um sistema industrial inovador de construção de casas tanto de pequeno porte como de padrão médio e pequenos edifícios. Destaca-se na construção de casas populares por sua versatilidade, atendendo as necessidades atuais, sendo suas principais vantagens rapidez, produtividade e menores resíduos. Onde se tem grande demanda de entregas de residências em menor prazo possível, utilizando menos recursos, diminuindo gastos e com qualidade, torna-se menos expressivo seu maior custo em comparação com o método construtivo convencional, mostrando-se como a melhor forma de se construir nesse sentido. Um sistema promissor que desponta como uma resposta à construção civil atual levando em consideração a questão ambiental, econômica e social, associado à industrialização atendendo as expectativas tecnológicas. Por isso tornar-se imprescindível o estudo e pesquisa tanto para entender e conhecer esse sistema, suas etapas, métodos e técnicas, ampliar os conhecimentos e promover melhorias e adaptações nesse sistema, difundindo ele cada vez mais.

\section{5 - Referências}

CAMPOS, Alessandro de Souza. O que é o Light Steel Framing. IBDA - Fórum da Construção. $2012 . \quad$ Disponível em: <http://www.forumdaconstrucao.com.br/conteudo.p $\mathrm{hp} ? \mathrm{a}=29 \& \mathrm{Cod}=85>$. Acesso em: abr. 2014.

CONSTRUÇÃO, Redação do Fórum da. Light Steel Framing, Versatilidade, Rapidez $\mathrm{Na}$ Montagem E Um Excelente Acabamento. IBDA Fórum da Construção. 2012. Disponível em: <http://www.forumdaconstrucao.com.br/conteudo.p $\mathrm{hp} ? \mathrm{a}=8 \& \mathrm{Cod}=484>$. Acesso em: abr. 2014.

FREITAS, Arlene Maria Sarmanho; CRASTO Renata Cristina Moraes de. Steel Framing: Arquitetura. 1. ed. Rio de Janeiro: IBS/CBCA, 2006. 121 p.; $29 \mathrm{~cm}$. (Série Manual de Construção em Aço). ISBN 85-89819-09-4.

MILAN, Gabriel Sperandio; NOVELLO, Roger Vagner; REIS, Zaida Cristiane dos. A Viabilidade Do Sistema Light Steel Frame Para Construções Residenciais. Revista Gestão Industrial, Ponta Grossa, v. 07, n. 01, p. 189-209, 2011.

NETO, Abdala Carim Nabut; SPOSTO, Rosa Maria. Sustentabilidade energético ambiental de fachadas aplicada ao sistema steel frame. In: VI Encontro Nacional e IV Encontro Latinoamericano sobre Edificações e Comunidades Sustentáveis, Vitória-ES, 2011. Disponível em: <http://www.elecs2013.ufpr.br/wp-

content/uploads/anais/2011/2011_artigo_149.pdf>. Acesso em: mar. 2014.

SANTOS, Fábio Rocha et al. Metodologia da pesquisa. São Paulo: Pearson Prentice Hall, 2010. 228p. ISBN 9788576057369.

www.uniube.br/entec - UNIUBE Campus Aeroporto - Uberaba/MG 